Marcin Sktadanowski

The John Paul II Catholic University of Lublin

\title{
Anthropological Arguments in an Interconfessional Discussion of Homosexuality
}

\section{ARGUMENTACJA ANTROPOLOGICZNA W MIĘDZYWYZNANIOWEJ DYSKUSJI NAD HOMOSEKSUALNOŚCIĄ}

Tekst koncentruje się na antropologicznym fundamencie zagadnienia homoseksualności poruszanego we współczesnej teologii ekumenicznej oraz w dialogach międzykościelnych. Okazuje się, że adekwatne rozwiązanie istniejących między denominacjami rozbieżności w nauczaniu etycznym nie jest możliwe jedynie na poziomie wyznaniowej doktryny etycznej (moralnej), lecz musi sięgać do jej antropologicznych fundamentów. Wydaje się zresztą, że nowy język używany zarówno przez poszczególne denominacje chrześcijańskie, jak też przez gremia ekumeniczne w odniesieniu do zjawiska homoseksualności ma swoje korzenie właśnie w świadomości, iż koncentracja na nauczaniu moralnym bez pogłębienia jego podstawy antropologicznej nie pozwoli chrześcijanom na adekwatne ujęcie tegoż zjawiska oraz na dialog ze współczesną kulturą zachodnią, coraz bardziej otwarcie odrzucającą klasyczne chrześcijańskie zasady etyczne.

Artykuł naświetla najpierw znaczenie problemu homoseksualności dla samego ruchu ekumenicznego. W dalszym etapie przedstawia wybrane wypowiedzi dialogowe na temat homoseksualności. Następnie wypowiedzi te wraz z treściami obecnymi we współczesnej debacie teologicznej stają się podstawą do ukazania typologii argumentacji antropologicznej.

Słowa kluczowe: homoseksualność, sprawiedliwość płciowa (genderowa), etyka, ekumenizm, dialogi ekumeniczne. 


\section{Introduction}

The issue of homosexuality or, in a broader context, of non-standard ways of expressing one's sexuality by men and women is currently a topic of widespread public debate concerning socio-political as well as ethical matters. It has long since extended beyond the realm of medicine and psychology to become an important and controversial world-view issue. It is also not merely a theoretical matter. The public debate on homosexuality in developed countries not only contributes to a change in the way homosexual people are perceived in general, but also manifests itself in changes in state legislation that guarantee equal treatment of homosexual people in different spheres of life and prohibit any acts of discrimination which are sometimes subject to criminal penalties. Therefore, the fact that homosexuality is publicly debated has important consequences both for the social and personal lives of people living in the Western world. These consequences do not only pertain to homosexuals themselves, but also affect other members of society.

This article focuses on the anthropological foundations of the issue of homosexuality, which is discussed in contemporary ecumenical theology and which, to a limited extent, is a topic of inter-Church dialogues. Today it is impossible to arrive at an adequate solution to the existing discrepancies between the ethical teachings of different denominations only at the level of religious ethical (moral) doctrine, i.e. one must reach the anthropological foundations of a given doctrine. It seems that the new language that is used both by particular Christian denominations and by ecumenical groups in reference to homosexuality has its roots in the very awareness that a focus on teaching about morality without gaining insight into its anthropological basis will make it impossible for Christians to take an appropriate approach to this phenomenon and to engage in a dialogue with contemporary Western culture, which is increasingly more often openly rejecting traditional Christian ethics.

In order to outline the way in which anthropological arguments pertain to homosexuality, as well as their significance - in accordance with the principles of the ecumenical movement - first homosexuality's importance as an issue to the ecumenical movement itself will be highlighted. Then selected parts of the dialogue about homosexuality will be presented. Next, these statements, together with opinions expressed in the contemporary theological debate will provide a basis for preparing a typology of anthropological arguments. 


\section{Homosexuality as an ecumenical matter}

As homosexuality has become a very popular socio-political and ethical issue, thus it more frequently appears in the statements of the various Churches. Theologians representing different denominational traditions who are less bound by the norms of a particular religious ethical doctrine than the official representatives of the Churches are even more willing to discuss this topic. These opinions no longer echo the former voices which clearly rejected homosexuals or condemned their lifestyle; they are, however, more nuanced. In particular, homosexual practices are differentiated from the very fact of being a homosexual person ${ }^{1}$.

The contemporary statements of the theologians and Churches are more balanced also because today's Christians, especially those living in Western countries, function in a social and political reality where homosexuality is accepted - at least in theory or by law - and acts manifesting the rejection of homosexuals may be punished. This changed context of Church statements is leading Christians to rethink their moral evaluation of homosexuality. This is also accompanied by theology's increased interest in sexual matters ${ }^{2}$ which are not only discussed from the perspective of moral norms, as was the case until recently, but primarily from a deeper, anthropological perspective. It is mostly Christian denominations which critically examine their own moral teachings that reflect on these issues. For example, this resulted in the issuing of two important documents: Zwischen Autonomie und Angewiesenheit ${ }^{3}$ and LWF Gender Justice Policy ${ }^{4}$.

However, as moral questions are also addressed in the majority of dialogues held between the Churches, the issue of homosexuality is discussed by the representatives of the ecumenical movement as well. But while theologians who represent different denominational traditions are willing to make attempts to revise their moral assessment of homosexuality, official dialogue documents confirm that this is still an issue that divides the Churches and that, for now, there is no solution that would be satisfactory for all the participants in the dialogue. What is more, this division seems to be becoming sharper. The Catholic

E.g. Catechism of the Catholic Church, 2358.

2 M. Althaus-Reid, On Queer Theory and Liberation Theology: The Irruption of the Sexual Subject in Theology, "Concilium" 1/2008, p. 88-89.

3 The Evangelical Church in Germany, Zwischen Autonomie und Angewiesenheit. Familie als verlässliche Gemeinschaftstärken. Eine Orientierungshilfe des Rates der Evangelischen Kirche in Deutschland (EKD), Gütersloh 2013.

4 The Lutheran World Federation, Gender Justice Policy, Geneva 2013. 
Church (similarly to the Orthodox Churches) is considered, also by progressive Catholic theologians, to be particularly negatively disposed towards homosexuality ${ }^{5}$ and also uncompromising as far as attempts to change its traditional moral teaching are concerned. Meanwhile, many Protestant communities, with the exception of fundamentalist (evangelical) groups, are definitely changing their stances, not only by accepting the fact that a certain number of their faithful have a homosexual orientation, but also by supporting Christian gay and lesbian movements ${ }^{6}$ or by working on the possibilities of recognising same-sex marriages in a Christian sense ${ }^{7}$.

Apart from the problem of the widening differences between the official positions of the Churches on homosexuality, the need for a reliable Christian testimony relating to the issue is another important factor behind interdenominational theological reflection on it, also with regard to anthropology, in this changing world, where the traditional Christian guidelines and moral judgements are often no longer accepted or even understood. In this context, Christianity is accused of being ossified, dogmatic and of giving theology an ideological character, which is supposed to manifest itself in a lack of sensitivity to the different experiences and living circumstances of minority groups or an unwillingness to engage in a dialogue. And this is what - according to those who are criticising the traditional stance of Christianity - leads many people, not only homosexual, to cut ties with official Churches ${ }^{8}$ which reject many men and women in the name of certain ideological assumptions.

\section{Selected statements from the dialogue}

Although dialogue documents devoted to ethical issues are increasingly more often dealing with homosexuality, it should be noted that the amount of attention that is paid to this matter in such ecumenical documents does not reflect the real scale of the debate that is taking

$5 \quad$ R. Ammicht Quinn, 'We' and 'Others': In Place of an Introduction, "Concilium" 1/2008, p. 11-12; N. Reck, Dangerous Desires: Catholic Approaches to Same-sex Sexuality, "Concilium" 1/2008, p. 15.

6 J. Coleman, The Homosexual Revolution and Hermeneutics, "Concilium" 3/1984, p. 59-60; E. Stuart, Lesbian and Gay Relationships: A Lesbian Feminist Perspective, [w:] Christian Perspectives on Sexuality and Gender, ed. E. Stuart, A. Thatcher, Herefordshire-Grand Rapids 1996, p. 305.

Zwischen Autonomie und Angewiesenheit, 65-66.

M. Althaus-Reid, A Woman's Rights to Not Being Straight (El Derecho a no ser Derecha); On Theology, Church and Pornography, "Concilium" 5/2002, p. 89, 94. 
place within the Churches, as the second half of the $20^{\text {th }}$ century was, for many of the Churches, especially the Protestant ones, a time of critical reflection on their own moral doctrines. This period has not ceased with the changes that these Churches introduced to their pastoral practice. Moreover, even the relatively few mentions of homosexuality indicate that it is impossible for the Churches to reach a substantial agreement at the present stage of ecumenical reflection. For this reason the existing texts attempt to emphasise the common Christian anthropological foundations while at the same time slightly marginalising or blurring the discrepancies.

\section{Images of God}

A document which was prepared in 1983 by an Anglican-Catholic commission for dialogue in the United States and which dealt with matters related to Christian anthropology emphasises the importance of the marital bond. At the same time there is a strong tendency in public life, also in church circles, towards noticing intimacy that is typical of marriage in interpersonal relations other than marriage (which is still understood as the relationship between a man and a woman only) ${ }^{9}$.

The document points out that it is necessary for homosexual tendencies to be differentiated from homosexual acts. According to the participants in the dialogue who refer to their Church's official teachings, homosexual acts, similarly to heterosexual acts outside of marriage, are morally wrong. This text also points to an anthropological motivation behind this negative evaluation: a homosexual relationship - even if it is deep and characterised by faithfulness as well as selfless love does not conform to the image of marriage created in God's likeness which is presented in Scripture and which is manifested as a union between a man and a woman being of "one body" (Gen 2:24). That is why a homosexual relationship cannot be sanctified by the sacrament of marriage ${ }^{10}$ - Jesus Christ refers to this very close union which is a manifestation of God's calling (Matt 19:3-9).

The above-mentioned differentiation between homosexual tendencies and homosexual acts also leads the parties of the dialogue to another conclusion. This document clearly confirms homosexual people's right to dignity as they have been made in the image of God.

9 Anglican-Roman Catholic Consultation USA, Images of God: Reflections on Christian Anthropology, n. 39, http://www.usccb.org/beliefs-and-teachings/ecumenical-and-interreligious/ecumenical/anglican/images-of-god-anthropology. cfm [30.07.2014]. 
It points out that when this right was forgotten, homosexuals were often persecuted and treated unjustly by other people. This unjustness was sometimes manifested in the life of the Christian community, from which homosexual people were excluded. Therefore, this reminder of their dignity is also a call for Christians to eliminate, as soon as possible, any real manifestations of exclusion or discrimination ${ }^{11}$.

\section{Implications of the Gospel}

In 1988 a dialogue group of Lutherans and Anglicans (the Episcopal Church) in the United States presented a text dealing with the implications of the Gospel for the Churches as well as for different spheres of life and the conduct of Christians. This document also draws attention to the difficulties related to the change that is taking place within the Churches with regard to the evaluation of homosexuality. It points out that, on the one hand, this issue is connected with the Christian vision of a human being that has its roots in the Bible and, on the other hand, there is no consensus among Christians on the interpretation of biblical texts about homosexual practices. Some think that a faithful interpretation of the Bible makes it impossible to accept homosexual practices, while others believe that the Holy Scriptures do not provide any clear or binding guidelines in this respect. In this context the authors of the document draw attention to the fact that Christians themselves increasingly often express doubts about this matter. Many believers do not accept the absolutely negative assessment of all forms of homosexual behaviour. Although the Churches still have not formulated a coherent position on this issue, it is obvious for the authors of the text that they should be primarily guided by wisdom, love and compassion ${ }^{12}$.

The lack of such a stance is also thought to encourage the Churches to further study this matter by, most of all, focusing on the implications of the Christian vision of a human being, the dignity of every person as well as men's and women's ultimate calling. Here, the question arises whether it would not be advisable to look at the differences in the sexual orientation of many men and women, which do not result from voluntary decisions, in a different manner even though one recognises people's mission to create life in a marriage. Therefore,

\footnotetext{
11 Ibidem, n. 40.

12 Gruppo di dialogo fra luterani ed episcopaliani negli USA, Le implicazioni del Vangelo, n.119a,[in:] Enchiridion Oecumenicum.Documenti del dialogo teologico interconfessionale, vol. 4: Dialoghi locali 1988-1994, G. Cereti, J. F. Puglisi (ed.), Bologna $1999^{2}$, p. 2772.
} 
Christians should think over the many examples of the condemnation of homosexuality in the Churches' traditional moral teachings and especially reconsider the soundness of identifying homosexuality with promiscuity, which happens frequently. When formulating their own teaching and practices, the Churches should not forget that they cannot exclude any minority group while carrying out their mission, which is testimony to the truth that no human being is excluded from gracious God's saving activity ${ }^{13}$.

\section{Life in Christ / Christian Ethics in the Ecumenical Dialogue}

An extensive document about an international dialogue between Catholics and Anglicans which was issued in 1993 and which deals with ethical matters mainly aims to point to the far-reaching similarity between the teachings of both Churches. This is why it devotes less attention to the differences. This also refers to homosexual practices. The document emphasises the common anthropological vision that is based on the biblical truth about human sexuality which is a part of God's plan for creation. Marriage between a man and a woman is the fullest manifestation of their calling to create interpersonal communion. At the same time it is highlighted that human sexuality is expressed in a multitude of bodily, intellectual, emotional and spiritual experiences. Given the abundance of forms it is manifested in, sexuality shapes all the relations that are part of a human being's existence ${ }^{14}$.

A fundamental anthropological consensus on this matter does not, however, translate to similarities in moral teachings with regard to intimate interpersonal relations other than a permanent relationship between a man and a woman. The document indeed states that one cannot consider homosexual relations as having the same value as marital relations. However, while the Catholic Church says that homosexual relations are internally chaotic and regards them as morally wrong, the Anglican Church agrees with the opinion about the lack of internal order in such relationships but at the same time does not feel entitled to make an unequivocally negative moral judgement ${ }^{15}$. The differences in doctrine and pastoral practice do not, however, prevent Catholics and Anglicans to jointly state that homosexual people derive

$13 \quad$ Ibidem, n. 119b-c, p. 2773-2774.

14 ARCIC II, Life in Christ: Morals, Communion and the Church, n. 55, in: Growth in Agreement II. Reports and Agreed Statements of Ecumenical Conversations on a World Level, 1982-1998, J. Gros, H. Meyer, W. G. Rusch (ed.), Geneva 2000, p. 358

$15 \quad$ Ibidem, n. 87,366 . 
their inalienable personal dignity from the fact of being created in the image of $\operatorname{God}^{16}$.

The statements made as part of this international dialogue are echoed in an Anglican-Catholic document, issued in 1995 in the United States, which presents an opinion that the existing discrepancies between the positions adopted by the Churches mainly concern pastoral practice and, as such, do not contradict the common Christian testimony of the importance of the union of a man and a woman ${ }^{17}$.

\section{Growth in Communion}

Here it should be noted that a document prepared in 2002 relating to an international dialogue between Anglicans and Lutherans also deserves attention. It reflects the tension existing within the Churches themselves in connection with the change of the norms and practice regarding homosexual people which has been introduced by various ecclesiastical provinces of the Anglican Church or national Lutheran Churches. Difficulties within the Churches are mostly related to the fact that it has become possible for people living in homosexual relationships to be ordained and to provide spiritual ministry as well as to the fact that such relationships can be blessed. However, the document does not give any guidelines that would help to relieve this tension. It rather makes an observation that resolution of such difficulties is sometimes beyond the capabilities of the Churches. Therefore, Christians should seek new solutions, also through theological dialogue and by learning from one another ${ }^{18}$.

\section{A typology of anthropological arguments}

Although there are relatively few statements made as part of the dialogue about homosexuality, one can notice the primacy of anthropological arguments, which have also dominated the contemporary theological literature. Christians' attitude towards homosexual people

$16 \quad$ Ibidem, n. 87-88, 366.

17 Anglican-Roman Catholic Consultation USA, Christian Ethics in the Ecumenical Dialogue: Anglican Roman Catholic International Commission II and Recent Papal Teachings, n.2, http://www.usccb.org/beliefs-and-teachings/ecumenicaland-interreligious/ecumenical/anglican/ethics-in-ecumenical-dialogue.cfm [30.07.2014].

18 Anglican-Lutheran International Working Group, Growth in Communion, n. 154, http://www.anglicancommunion.org/ministry/ecumenical/dialogues/lutheran/ docs/growth_in_communion_report.cfm [30.07.2014]. 
is changing. Their previous evaluations condemning the lifestyle of homosexuals are becoming more moderate as they refer to the dignity of all human beings, regardless of their world view, as well as to men's and women's inherent freedom of self-determination and the freedom to shape one's own life ${ }^{19}$. These arguments are based on several fundamental ideas.

\section{The dignity of and the equality between all people}

Ecumenical texts point out that it is necessary to reflect on specific ways of showing Christian concern for respecting every human being's right to dignity and the resulting equality between all people which should not only be recognised by the lay community (by means of legislation that guarantees this equality), but also and primarily by Christian communities, as this equality is related to the bond existing between every human being and God, which is symbolically expressed in the saying that all people have been created "in the image and likeness" of God. This raises doubts as to whether proclamations that all men and women, including homosexual men and women, have an equal right to dignity are reliable if they are not accompanied by activities aimed to resist discriminatory practices ${ }^{20}$.

\section{The inner richness of a human being}

The various dialogue statements also refer to the inner richness of a human being which is not only limited to the realm of instincts or sexual behaviour, but which manifests itself in all aspects of one's personality as well as in one's life experiences. Attention is drawn to the fact that the unreal manner in which homosexual people are portrayed may also influence certain Church statements, in which human sexuality is unnecessarily emphasised ${ }^{21}$ or, more precisely, which only concentrate on some dimensions of sexuality. Consequently, the inner richness of homosexual people may be disregarded in Church language, which may grotesquely describe them solely through the

19 M. Składanowski, Polityka sprawiedliwości genderowej Światowej Federacji Luterańskiej, [in:] O ekumenizmie w Roku Wiary, P. Kantyka, P. Kopiec, M. Składanowski (ed.), Lublin 2013, p. 210-211.

$20 \quad$ Ibidem, 208; J. Clague, The Moral Values of Europe: Marks Or Wounds of Civilization, "Concilium" 1/2008, p. 33.

21 The Promise of Lutheran Ethics, K. L. Bloomquist, J. R. Stumme (ed.), Minneapolis 1998, p. 169. 
prism of sexual practices, as if these were the only element of human experiences $^{22}$.

Teologia rodziny

\section{A human being's freedom and right of self-determination}

The nuanced language used in the dialogue statements indicates that Christians, by emphasising the significance of human dignity and the necessity to defend it in the contemporary world, are attaching increasingly more importance to the freedom of a human being, which also manifests itself as men's and women's freedom of self-determination. In this context, attention is drawn to every human being's right to be different and to express the fact that people can be different. Some theologians perceive the granting of the right to express one's sexual orientation to homosexual people as the true liberation of human beings, which should also be the Churches' aim ${ }^{23}$.

\section{The purpose of sexual differentiation}

Even though the dialogue documents invariably contain a Christian affirmation of marriage between a man and a woman, which is also related to the task of creating life, it seems that this aspect is becoming somewhat less important in anthropological reflection. This is connected with the fact that fertility, as an aspect that is essential to the usefulness of marriage, is increasingly more often openly questioned by progressive trends in Christian theology. In such an approach, sexual differentiation would not necessarily, or not primarily, serve procreation, but it would be a manifestation of a human being's inner richness. However, if openness to giving life loses its primary importance then this raises doubts as to whether the Churches should still definitely reject the possibility of men and women leading a different lifestyle that would be based on mutual love and faithfulness ${ }^{24}$.

\section{A testimony of love}

Despite the acknowledged differences between the Churches, the theme of love that Christians should have for all people, even for those whose behaviour or views are not compatible with a given Church's doctrine or practice, runs through ecumenical statements devoted to

$22 \quad$ R. Ammicht Quinn, 'We' and 'Others', p. 10.

$23 \quad$ M. Althaus-Reid, A Woman's Rights to Not Being Straight, 91; On Queer Theory and Liberation Theology, p. 85-86.

R. Ammicht Quinn, 'We' and 'Others', 11; N. Beck, Dangerous Desires, p. 22. 
reflection on homosexuality. This is also why many Churches refrain from making unequivocal judgements about the conduct of homosexual people ${ }^{25}$. It seems that the call for true love which respects every man's and every woman's dignity is a special testimony of Christian concern for human beings. This concern assumes that, although there are doctrinal and practical difficulties related to accepting the behaviour of certain groups of men and women, Christians will never resort to hate and rejection of, or discrimination against, such groups, as such reactions would actually amount to the denial of Christian teachings ${ }^{26}$.

\section{Conclusions}

The presented ecumenical statements about homosexuality and the anthropological arguments they use, although with a different degree of emphasis, provide a basis for the renewal of the Christian Churches' ethical teachings. Generally speaking, conservatives claim that this renewal mostly entails a progressive liberalisation, which is an actual concession to "the spirit of this world". One cannot, however, forget that this is a consequence of the changing social context in which Christians live. Given the social transformations and the related changes in the civil law, the Churches have both the right and the duty to ask themselves a question about whether the traditional ethical teachings really correspond to the biblical vision of a human being and defend the truth about people's inalienable right to dignity or whether this doctrine was penetrated by foreign elements over the centuries of its development. Such elements might reflect the mentality and ethical judgements that were characteristic of a given epoch or cultural environment and which, in fact, are not compatible with the message of the Gospel. The fact that anthropological arguments are emphasised in interdenominational, Christian reflection on homosexuality is also connected with the changing situation within Christianity, in particular with the frequent observation that Christians themselves, who have grown up in a new cultural and social context, have doubts concerning the traditional way in which the Christian principles of conduct are presented and they also sometimes openly challenge these principles.

In the ecumenical discussion of homosexuality, anthropological arguments have caused the dignity of every human being to be emphasised, even if a given human being's lifestyle does not conform to the Christian principles of conduct. However, as such statements do

$25 \quad$ The Promise of Lutheran Ethics, p. 171

26 The Lutheran World Federation, Gender Justice Policy, p. 38. 
not eliminate all misunderstandings between the Christian Churches, ecumenical, anthropological debate must be further deepened and made more balanced. Churches such as the Catholic Church which, while recognising every human being's right to dignity, do not accept rodziny homosexual practices, draw attention to the fact that Christian anthropological and ethical thought emphasises the precedence of attempts to discover God's true will and of being faithful to God's Word over attempts to seek harmony with contemporary culture. God's Word, in its essence, does not depend on people's opinions or ideas which change over time and vary from place to place.

In this context it seems that truly Christian anthropology, which also aims to reinterpret the views on homosexuality, must take into account the concerns of those Churches and those Christian groups which consider the new versions of ethical doctrine that have been proposed by many denominations not as much a willingness to reject the distortions of Christian testimony as a manifestation of sacrificing the truth about a human being in the name of preserving a given Church's significance in changing Western societies. Meanwhile, what makes Christianity credible is not progressive views but faithfulness to God in any cultural and historical context.

Key words: homosexuality, gender justice, ethics, ecumenism, ecumenical dialogues. 